\title{
THE INFLUENCE OF HUMAN RESOURCES ACCOUNTING ON THE PERFORMANCE OF NIGERIA'S LISTED CONSUMER GOODS COMPANIES
}

\author{
Taibat A. Atoyebi ${ }^{1}$, Allwell Itegbe ${ }^{1}$ and Tirimisiyu Kunle Lasisi $^{2}$ \\ ${ }^{* 1}$ Department of Accounting, Faculty of Management Sciences, University of Abuja, Nigeria \\ ${ }^{2}$ Department of Accounting, Faculty of Management Sciences, Federal University of Lafia, Nigeria \\ *Correspondence: Taibat A. Atoyebi, Department of Accounting, Faculty of Management Sciences, University of \\ Abuja, FCT Abuja, Nigeria.
}

DOI: http://dx.doi.org/10.38193/IJRCMS.2021.3303

\begin{abstract}
The effect of human resources accounting practices on the performance of Nigerian consumer goods companies was investigated in this study. The study's population consists of thirty (30) publicly traded consumer goods companies in Nigeria. Using the filter criterion, twenty-four (24) of the identified consumer goods were sampled. Secondary data were compiled from selected firms' annual reports and accounts for six (6) years' worth of financial periods, spanning from 2013 to 2018. Using the multiple regression analysis method, the collected data was analysed. The study's findings revealed that the number of employees working during the time and overall assets have a positive relationship with the performance of Nigeria's publicly traded consumer goods companies. The study's findings revealed that leverage and the firm's age are negatively related to the performance of listed consumer goods firms in Nigeria. Furthermore, the study discovered that employee expansion and government (VAT) have no substantial relationship with the performance of Nigeria's publicly traded consumer goods firms. As a result, the study recommends that management of publicly traded consumer goods companies should weigh the number of employees when hiring because the larger the workforce, the higher the efficiency and profit potential of the company. Furthermore, management of publicly traded consumer goods companies should focus on providing sufficient total assets, as this leads to the generation of more economic gain to the company, resulting in increased profits.
\end{abstract}

KEYWORDS: Employee Expansion, Performance, Leverage, Age, Total Assets

\section{INTRODUCTION}

Employees are one of a company's most valuable assets because the majority of organizational activities that determine performance rely on employee effort. As a result, personnel are commonly referred to as human resources in today's corporate strategy and business jargon. Human resource is a term that refers to the group of people who make up the workforce of an organization or business entity. It consists of people's energies, skills, talents, and expertise that are or could be applied to the development of products or the provision of useful services (Syed, 2009). Human resources are the 
most valuable assets a company can have because they allow it to effectively and efficiently leverage other resources such as property, facilities, and capital.

However, organizations struggle to quantify any relevant data relating to human capital, particularly when it comes to accounting for its value as an asset in financial statements. This is due to the fact that, while Human Resource Accounting considers human capital to be assets or investments that must be retained for long-term productivity, it cannot be considered a fixed asset in the strict sense. Labor mobility and ethical concerns are two more reasons why Human Resources Accounting should not be fully institutionalized in corporate financial statements. Human resource accounting is the process of defining, evaluating, and disseminating data about human resources to interested parties. Okpala and Chidi (2010) defined human resource accounting as the monetary quantification of an organization's human resources. They contend that a well-developed human resource/capital accounting system will assist management in making better internal decisions and investors in making better external decisions.

It is impossible to overestimate the value of human resources in any business. Despite the fact that the definition of human resource accounting has been around for a long time, it is still not widely accepted (Bowers, 2003). Many authors and academics have investigated how humans in an organization can be valued and recorded in that organization's financial statements (Schulz, 2001; Hermannson, 2004; Likert, 2007; Bowers, 2003; Flamholz, Bullen and Hua, 2002). Human resource accounting and reporting by corporations is also in its infancy in Nigeria. This can be seen as the reason why these companies' investments in human capital growth are typically expensed rather than recorded as assets on their balance sheets. Okapla and Chidi, 2010; Micah, Ofurun, and Ihendinihu, 2012). The major challenges in recognizing human capital as an asset are primarily related to its characteristics, monetary quantification, and reporting methods.

As a result, some schools of thought believe that money spent on human resource development should be capitalized in order to increase efficiency and financial success. At this point, the issue emerges as a means of demonstrating that human resource accounting has an effect on the solvency of the organization. There must be corresponding "tangible evidence" in the financial statements for its contribution, representing the related increase in the organization's net worth and assets. The purpose of this study therefore, is to investigate the impact of employee expansion, number of employees, leverage, government, age, and total assets on the output of Nigerian listed consumer goods companies. To accomplish this, the researchers developed the following hypotheses:

i. HO1: There is no connection between employee expansion and the performance of publicly traded consumer goods companies.

ii. HO2: There is no connection between the number of people employed and the performance 
of Nigerian consumer goods companies.

iii. HO3: In Nigeria, there is no substantial connection between leverage and the performance of publicly traded consumer goods companies.

iv. HO4: In Nigeria, there is no substantial connection between government and the performance of publicly traded consumer goods companies.

v. HO5: In Nigeria, there is no connection between age and the performance of publicly traded consumer goods companies.

vi. vi, HO6: There is no significant relationship in Nigeria between total assets and the performance of publicly traded consumer goods companies.

\section{CONCEPTUAL REVIEW}

\subsection{Concept of Human Resources Accounting}

Human resources, according to Micah, Ofurum, and Ihendinihu (2012), are people's energies, skills, talents, and knowledge that are, or potentially can be, applied to the production of goods or the provision of useful services. Human resource accounting (HRA) is the evaluation and reporting of the cost and benefit of people in an organization's capital (Flamholtz, 2011). It is a method of identifying, analyzing, and disseminating data about human capital to those who are interested. The American Accounting Association (1973) defines HRA as "the method of identifying, calculating, and transmitting data regarding human capital to accounting information users." Human resource accounting, according to Jawahar Lal (2009), is not only useful to management in achieving economic goals, but it can also be a source of valuable information for investment decision-making. Incorporating adequate human resource data into publicly accessible financial statements would almost certainly improve their usefulness in predicting future performance, which is, of course, investors' primary concern.

According to Okpala and Chidi (2010), human resource accounting is the monetary calculation of an organization's human capital. According to Bullen and Eyler (2010), human resource accounting involves accounting for human resource expenses as properties, as opposed to traditional accounting, which treats these costs as expenditures that reduce benefit. Woodruff (1970, cited in Enyi \& Akindehinde, 2014) defines human resources accounting as "the description, compilation, and distribution of knowledge about Human Resources in dollar or naira terms." Thus, human resource accounting is simply the accounting for the importance of people in an organization in order to boost financial information users' understanding and help them make informed decisions (Enyi \& Akindehinde, 2014). Seth (2009) defines Human Resource Accounting (HRA) as "accounting for people as original resources," and it is the measurement of an organization's human cost and profit. It's also a way of thinking about how people are treated in hierarchical structures. He confirmed that worker experience is a valuable resource for a typical modern business enterprise, and that the need for experienced workers increases as business organizations become more complex, despite financial 
reporting ignoring such resources.

\subsection{Human Resource Accounting Disclosure}

The act of disclosing all relevant information about a company's workers that could affect an investment decision is known as human resource accounting disclosure. Hansson (2012) is an author who has written a number of books on the subject. Human resource accounting disclosure (HRAD) was determined by developing an index consisting of fifteen (15) discretionary human capital disclosure items, according to Kellonway and Barring (2000) and Syed (2000). (2009). Kellonway and Barring (2000) and Syed (2000) also list the things of human capital that must be revealed (2009). i. Separate HRA statement, ii. Total value of Human Resource (HR maintenance cost), iii. Number of Employees, iv. Human Resource Policy, v. Training \& Development, vi. Management Succession Plan vii. Employees' Value Creation, ix. Human Resource Development Fund, x. Employees/Workers Fund, xi. Employee groups, xii. Managerial remuneration, xiii. Retirement benefits, xiv. Performance Recognition, and xv. Pension fund.

\subsection{Challenges of Human Resource Accounting}

Human resource assessment and reporting, as previously noted, are not without challenges, which have been reported in previous research works. According to Sveiby (2007), while some businesses calculated their human capital, they did not include the value in their annual reports as assets, arguing that such a practice is unnecessary given the existing accounting definition, which lacks a model, laws, and regulations for this form of reporting. Furthermore, companies are wary of divulging too much information. The slow development of the principle of documenting human resource value was also noted by Edward and Garyl (2001). This, they argue, is due in large part to its lack of proven accounting usefulness. Sveiby (2007) reinforced this argument by demonstrating that, while theoretically appealing, efforts to turn individuals or competencies into monetary terms had yet to prove useful to managers.

According to Flamholtz (2009), the most significant obstacles in human resource accounting are valuation issues, inherent uncertainties in the value to be included in the financial statement, and the potential for fraudulent manipulations. The challenges of HRA in Nigeria, according to Ifurueze, Odesa, and Ifurueze (2014), include:

i. There are no concrete and well-defined criteria for determining the importance of an organization's human capital.

ii. Human capital, unlike tangible properties, cannot be owned, retained, or used at the discretion of the company.

iii. Difficulty calculating acceptable amortization rates.

iv. There is insufficient empirical evidence / proof to back up the claim that HRA aids in more effective and productive human resource management. 
v. Since human capital have an unpredictably short lifespan, valuing them in specific circumstances seems to be unrealistic.

There is no rule, norm, or policy that supports or enforces the use of HR.

\subsection{Classification of Performance Proxies}

For a long time, a company's success was judged solely on its ability to generate profit, i.e. financial metrics (Costea, 2006). Nonfinancial metrics such as intangible asset acquisitions, on the other hand, may be stronger predictors of future financial performance than historical measures, but this has improved with time, and businesses can now report these indicators (Andrea, 2010). As the concept of performance has evolved, a plethora of metrics have emerged, been classified, and are being used in a variety of ways to ensure that the information provided meets the needs of all stakeholders. Financial measurement is one of the tools used to assess financial capacity, weakness, opportunities, and threats (Tian \& Zeihim, 2007). Management often uses financial metrics (such as Return on Asset (ROA), Return on Equity (ROE), Return on Investment (ROI), Return on Investment (RI), Earnings per Share (EPS), and Dividend Yield) to measure, report, and improve the performance of the business.

Furthermore, performance must be measured using a balanced multidimensional method that includes both financial and non-financial metrics in order to obtain an economic entity's global condition at a given time. The most simple, transparent, and practical financial planning resources available are financial ratios (Majed, Abdel \& Firas, 2010). Internal and external consumers of financial data use them to make economic decisions. Increased profitability, improved productivity, and increased production would all contribute to improved and increased firm success (Alan, Saul \& Mark, 1999). As a result, financial and non-financial percentages, as well as variables, are used to calculate these classifications and factors. Financial performance variables include commonly used metrics relating to assets, investments, and owner's equity, such as levels, growth, and variability in earnings (Noel, John \&Scott, 1990). These ratios include market value, assets, cash flow, equity, revenue, and others. There are two types of financial ratios: classic and modern financial ratios. On the other hand, nonfinancial ratios are considered and estimated as environmental, strategic, formal, and informal variables. Human resource management performance and human resource skills are two examples. Despite the fact that financial accounting metrics (classical ratios) are subject to a variety of prejudices (negative opinions) not present in market-based indicators (modern ratios), they are widely regarded as accurate in reflecting a firm's financial health.

\section{EMPIRICAL REVIEW}

Ndubuisi and Obi (2019) looked into the effect of human resource accounting on the financial performance of Nigerian deposit money banks. The basic goals are to determine if personnel costs 
have an effect on return on asset, return on equity, and market-to-book valuation of banks listed on the Nigerian Stock Exchange's floor from 2010 to 2015. This study used an ex-post fact analysis style. Secondary data was obtained from the Nigeria Stock Exchange's publications and were analysed using Co-efficient of correlation and Ordinary Least Square (OLS) regression analysis. The findings of this study revealed that human resource accounting has a positive and statistically significant impact on financial performance at a $5 \%$ significance level.

The effect of human resource accounting on the performance of Nigeria's publicly traded banks was investigated by Oziegbe and Ofe (2018). The study examined the annual reports of 18 publicly listed commercial banks from the 2009 to 2017 financial years using an ex-post facto research design. Regression analysis was used to investigate the effects of human resource accounting attributes such as personnel expense, director remuneration, number of employees, and firm scale. Employee costs, employee strength, firm size, and financial results are all related, according to the findings. There was no connection between director pay and financial performance.

Rahim, Atan, and Kamaluddin (2017) investigated the relationship between human resource efficiency and firm performance in the Malaysian technology industry. Using accounting data, this study looked at the annual reports of all technology companies listed on Bursa Malaysia's Main Market and Ace Market in 2009. The research evaluated human capital performance using Ante Pulic's Value Added Intellectual Coefficient (VAICTM) methodology. In terms of human resource production, the results showed no difference between the Main Market and the Ace Market. Human resource productivity has a significant and optimistic relationship with firm performance, according to the results of the correlation report.

The relationship between human resource accounting and organizational performance was examined by Adebawajo (2015). In Nigeria, the thesis investigated the effect of human resource accounting on company performance. The studies used an empirical Ex-post factor analysis design on a sample of 18 listed banks in Nigeria's capital market. The studies used primary data collected from respondents through a well-designed questionnaire with a six-step Likert Scale that was peer-reviewed and found to have Cronbach Alpha Coefficients of 0.807 and 0.870, respectively, for human resources and organizational performance. The hypotheses were tested using a simple regression model. Human resource accounting has a significant effect on a bank's profitability, and human capital knowledge is critical to the market value of the sampled companies in Nigerian banks, according to the findings.

Salman and Dandago (2013) used a sample size of 50 companies listed on the Nigerian Stock Exchange Market, as well as content analysis and 17 indices, to review human resources accounting disclosure in financial reports of Nigerian firms. According to the results, Nigerian companies tend to express themselves in narrative and qualitative terms rather than quantitative or monetary terms when 
it comes to human resource disclosure. More than half of the companies sampled disclosed data on 7 to 16 of the 17 products, indicating that companies in Nigeria preferred some approach that was advantageous to them in disclosing human resources accounting information. The degree of human resources accounting transparency, according to the study, is below average.

Enofe (2013) looked into the financial disclosure of human resources in Nigerian publicly traded firms. The aim of the study was to establish a connection between firm profitability and human resource accounting disclosures. They used data from the financial and non-financial industries, as well as a survey of 50 Nigerian Stock Exchange firms. The data was analyzed using various regression statistical approaches to determine the relationship between the variables. There is a connection between a company's financial performance and its degree of human resource accounting disclosure, according to the findings. According to the study, financial firms disclose human resources accounting information more than non-financial firms, and profitability, company size, financial leverage, and business styles all influence whether or not businesses disclose human resources accounting information in their annual report.

Aribaba, Olugbenga, Lateef, and Ajayi (2018) looked into the effect of human resource accounting disclosure on a group of Nigerian publicly traded companies' financial performance. The annual financial report index of the selected firms served as the dependent variable, while business profitability, firm size, financial leverage, and industry form served as proxies for human resource accounting disclosure. The information required for this study was gathered using secondary data. The population of the study is made up of 188 manufacturing and non-manufacturing companies that were listed in the Nigerian Stock Exchange annual report between 2011 and 2015, of which 20 were selected. For this study, simple random sampling techniques were used to select 20 manufacturing and non-manufacturing firms from the population. The findings were analyzed using descriptive statistics, correlation, and regression. According to the study, the independent and dependent variables had a positive co-efficient value of 0.565 .

\section{METHODOLOGY}

This study employs an ex-post facto research design to answer the research questions. Ex post facto analysis is a descriptive research process in which the phenomenon being investigated has already happened. The population of the sample is made up of Nigeria's thirty (30) publicly traded consumer goods firms as of January 4, 2020. The sample size was determined using the following filter criteria:

(i) From January 2013 to December 2018, the company must have been listed on the Nigerian stock exchange.

(ii) the organization must provide continuous data from December 2013 to December 2018 (6 years) to meet the study's requirements.

According to the above criteria, twenty-four (24) publicly traded consumer goods firms in Nigeria 
have full annual reports and accounts for the study period and thus meet all of the criteria. The selection of these organizations is based on the fact that they have very similar capital structures, both in terms of human capital and operations. For the six-year financial period 2013-2018, secondary data from annual reports and accounts of twenty-four (24) publicly traded consumer goods companies on the Nigerian stock exchange were used. To analyse the relationship and effect between the variables under review, the analysis uses the multiple regression technique. This is the foundation for answering research questions and putting research theories to the test. R-square, modified R-square, correlation, diagnostic test, multi-collinearity test, and regression shall be used as decision criteria.

\subsection{Variables Measurements}

Table 1: Variables and their Measurements in Summary

\begin{tabular}{|c|c|c|}
\hline Variables & Measurement & Authors \\
\hline EPS & $\begin{array}{l}\text { Log of a natural number of basic earnings per share for } \\
\text { the year }\end{array}$ & Ofurum \& Adeola, (2018) \\
\hline EXPN & $\begin{array}{l}\text { Log of a natural number of value added to employee } \\
\text { expansion in the form of salaries, bonuses, and other } \\
\text { benefits. }\end{array}$ & Edom, Inah \& Adanma (2015) \\
\hline NSEP & $\begin{array}{l}\text { Log of a natural number of Staff Employed for the } \\
\text { Period }\end{array}$ & Edom, Inah \& Adanma (2015) \\
\hline LEV & Non-current Liability/Total Equity & Oladele (2018) \\
\hline GOVT & $\begin{array}{l}\text { Natural } \log \text { of numbers of value added to the } \\
\text { government in the form of taxes. }\end{array}$ & Peter \& Simen (2011) \\
\hline Age & The year of incorporation -2020 & Bassey \& Arzizeh (2012) \\
\hline TA & Log of natural numbers of total asset & Perera \& Thirkaulala(2012) \\
\hline
\end{tabular}

\subsection{Model Specification}

The Edom, Inah, and Adanma, (2015) model was used with some modifications to suit this research work in line with the research objectives, questions, and hypothesis of the study.

The following is the model that was created for this analysis:

EPS = $\mathrm{f}($ EMEXP, NSEP, LEV, GOVT., AGE, TA)

$\mathrm{EPS}=\beta_{0}+\beta_{1} \mathrm{EMEXP}+\beta_{2} \mathrm{NSEP}+\beta_{3} \mathrm{Lev}+\beta_{4}$ Govt $+\beta_{5}$ Age $+\beta_{6} \mathrm{TA}+\varepsilon_{\mathrm{i}}$

Where;

EPS $=$ Earnings per Share

EMEXP stands for employees' expansion (value added to employees' expansion (salaries, wages etc.) 
NSEP stands for number of staff employed for the period

LEV stands for leverage (Debt-Equity)

GOVT stands for value added to government (Taxes)

$\mathrm{AGE}=$ stands for the year in which a company was established.

$\mathrm{TA}=$ Total Asset for the year

$\beta_{0}=$ Constant to be estimated

$\beta_{1}-\beta_{6}=$ coefficient to be estimated

$\varepsilon_{\mathrm{i}}=$ Stochastic error term

\section{RESULTS}

\subsection{Descriptive Statistics}

Table 2 shows the mean, maximum, minimum, and standard deviation for EPS, Number of Staff Employed (NSEP), Employees Expansion (EXPN), Government (GOVT), AGE, and Total Asset (TA) Leverage (LEV).

Table 2: Descriptive Statistics Summary

\begin{tabular}{lllll}
\hline Variables & Mean & Std. Dev. & Maximum & Minimum \\
\hline EPS & 1.185883 & 2.648711 & $8.92 \mathrm{e}+08$ & -4.130568 \\
EXPN & $4.18 \mathrm{e}+07$ & $1.54 \mathrm{e}+08$ & $8.92 \mathrm{e}+08$ & 18397 \\
NSEP & 986.625 & 981.6374 & 4207 & 0 \\
LEV & -5437319 & 1.672674 & 19.41 & 0 \\
GOVT & $6.91 \mathrm{e}+07$ & $3.04 \mathrm{e}+08$ & $3.00 \mathrm{e}+09$ & 0 \\
AGE & 60.95833 & 34.95989 & 154 & 14 \\
TA & $3.73 \mathrm{e}+08$ & $1.39 \mathrm{e}+09$ & $8.52 \mathrm{e}+09$ & 67895 \\
\hline
\end{tabular}

Source: Output from STATA 13.

Table 2 shows that the EPS has a minimum of -4.130 and a maximum of 21.735 , with an average of 1.185 and a standard deviation of 2.648. TA has the lowest standard deviation of 1.39, meaning that it makes the most contribution to the model, while EPS has a standard deviation of 2.648, EXPN has a standard deviation of 1.54, NSEP has a standard deviation of 981.637, LEV has a standard deviation of 1.672, GOVT has a standard deviation of 3.04, and AGE has a standard deviation of 34.959, indicating that their standard deviation is higher.

\subsection{Correlations Matrix}

Table 3 displays the Pearson correlation analysis matrix, which depicts the degree of interaction between the dependent and independent variables, as well as the independent variables themselves. Excessive correlation can result in multicollinearity, which can lead to erroneous conclusions and assumptions. It assists in evaluating the degree to which all independent variables are related. 
Table 3: Correlation Results

\begin{tabular}{l|lllllll}
\hline & EPS & EXPN & NSEP & LEV & GOV & AGE & TA \\
EPS & 1 & & & & & & \\
EXPN & 0.0790 & 1 & & & & & \\
NSEP & 0.3461 & 0.2243 & 1 & & & & \\
LEV & -0.0716 & -0.0389 & 0.1377 & 1 & & & \\
GOV & 0.1147 & 0.4545 & 0.1271 & -0.0338 & 1 & & \\
AGE & -0.0194 & 0.3724 & 0.4299 & 0.0149 & 0.1685 & 1 & \\
TA & 0.0848 & 0.0790 & -0.1348 & 0.0989 & 0.0609 & -0.0237 & 1 \\
\hline
\end{tabular}

Source: Output from STATA 13.

The results show that there is a good relationship between EPS, EXPN, NSEP, GOVT, and TA. However, there is a negative relationship between the LEV and the TA. The highest correlation between independent variables is 0.4545 between Employee Expansion and Government. According to Judge, Griffiths, Hill, Luthepohl, and Lee, a simple correlation between independent variables should not be considered harmful until it reaches 0.8 or 0.9 . (1985).

\subsection{Diagnostic Test}

A diagnostic test is run to ensure that none of the multiple regression assumptions are broken. As a result, the analysis tests for multicollinearity.

\subsubsection{Multicollinearity Test}

To ensure that there was no multicollinearity among the independent variables in the regression model, multicollinearity was diagnosed. Multicollinearity occurs in a regression model when two or more independent variables are closely correlated with one another. A high degree of correlation (linear dependence) among the independent variables in a regression model is known as multicollinearity (Gujarati \& Porter, 2009). The correlation matrix, which defines the relationship between the variables, and the variance inflation factor (VIF), which determines the intensity of the correlation between the independent variables, can also be used to measure multicollinearity. It's determined by regressing one variable against one another. 


\section{Table 4: Multicollinearity Test Results}

\begin{tabular}{l|l|l} 
VARIABLE & VIF & 1/VIF \\
\hline EXPN & 1.44 & 0.694266 \\
AGE & 1.36 & 0.734199 \\
NSEP & 1.30 & 0.769446 \\
GOVT & 1.26 & 0.791190 \\
TA & 1.05 & 0.951808 \\
LEV & 1.04 & 0.958126 \\
\hline Mean VIF & 1.24 & \\
\multicolumn{2}{c}{ Source: Output from STATA 13 }
\end{tabular}

Source: Output from STATA 13

Table 4 shows that the tolerance value for this analysis is in the range of 0.694266 to 0.958126 , which is higher than the threshold value of 0.10 . The highest VIF value is 1.44 , which is less than 10 (Gujarati $\&$ Porter, 2009). There is no proof of major multicollinearity in the study's results since all of the VIF values are below 10. As a result, collinearity does not appear to have a significant impact on the independent variables in this analysis, and a typical interpretation of the regression coefficient can be made.

\subsection{Regression Results}

The regression results for all the sampled Nigerian publicly traded consumer goods firms in the study are shown in Table 5. The modified R2 of the regression model is $16.70 \%$, indicating that the independent variables (Employees Expansion (EXPN), Number of Staff Employed (NSEP), Government (GOVT), AGE, and Total Asset (TA) Leverage (LEV)) employed in the model explain $16.70 \%$ of the difference in Earnings per Share (EPS) by sample firms. 
Table 5 Regression Results

\begin{tabular}{lllll}
\hline Mode Summary & \multicolumn{5}{l}{} \\
\hline No. of Observation & 5.78 & & & \\
F-statistic & 0.0000 & & & \\
Prob. > F & 0.2020 & & & \\
R-square & 0.1670 & & & Sig. \\
Adj. R-squared & 2.4174 & & & \\
Root MSE & Coefficient & Std. Err. & tatistic & Ste \\
\hline Variables & $1.18 \mathrm{e}-10$ & $1.57 \mathrm{e}-09$ & 0.07 & 0.940 \\
\hline EXPN (Employees Expansion) & 0.0012844 & 0.0002348 & 5.47 & 0.000 \\
NSEP (No. of Staff Employed) & -0.2311443 & 0.1234687 & -1.87 & 0.063 \\
LEV (Leverage) & $6.64-10$ & $7.48 \mathrm{e}-10$ & 0.89 & 0.010 \\
GOVT (Government) & -0.017703 & 0.0067484 & -2.62 & 0.053 \\
AGE (Age of the firm) & $2.92 \mathrm{e}-10$ & $1.49 \mathrm{e}-10$ & 1.95 & 0.026 \\
TA (Total assets ) & 0.9637696 & 0.4290044 & 2.25 & \\
(Constant) & & & & \\
\hline
\end{tabular}

Output from STATA 13.

Note: Significance levels are $1 \%, 5 \%$, and $10 \%$

Source: Output from STATA 13

\section{DISCUSSIONS}

The effects of multiple regression in table 5 are used to discuss the findings in this report.

The results from table 5 show that employee expansion has no significant relationship with the performance of Nigeria's listed consumer goods industry, as the p-value of 0.940 is higher than the $10 \%$ level of significance. This ensures that an increase or decrease in the number of workers expansion has no bearing on the listed companies' financial results. The findings are consistent with those of Oziegbe and Ofe (2018), who discovered a connection between employee expansion and staff expense, staff power, firm size, and financial results. This study's results are consistent with those of Alpheaus and Ihendinihu (2016). Human resource investments (employee expansion) have a positive significant effect on the development of listed consumer products, according to Oyinyechi and Ihendinidu (2018), Atube and Olufawoye (2014).

The coefficient for the number of workers working for the duration (NSEP) has a positive coefficient of 0.002 with a p-value of 0.000 , according to table 5. This suggests that there is a strong correlation between the number of employees working and the success of publicly traded consumer goods 
companies. This means that as the number of staff employed (NSEP) rises by one unit, the firm performance of listed consumer goods firms in Nigeria rises by 0.002. In other words, the higher the number of staff employed (NSEP), the higher the firm performance of listed consumer goods in Nigeria. The results of this study support those of (Oziegbe \& Ofe 2018) and Adebanajo, (2015), who found a positive relationship between the number of employees, staff ability, firm scale, and the output of listed consumer goods.

Table 5 shows that the leverage coefficient has a negative value of -0.231 and a $p$-value of 0.063 . It demonstrates that leverage has a negative relationship with the success of Nigeria's publicly traded consumer goods companies. This means that a corporation that has been financed with more debt will pay more interest, reducing the firm's earnings. This result contradicts Enofe's (2013) results, which found a positive and important relationship between leverage and manufacturing firm efficiency. The findings are consistent with those of Salman and Dandago (2013), who found that human resource accounting on debt and equity is below average. As a result, there is a negative correlation between leverage and the success of publicly traded consumer goods companies.

The coefficient of the government's proxied Value Added Tax is 6.64, with a p-value of 0.376. The findings indicate that the government's value added tax has no substantial impact on the success of Nigeria's publicly traded consumer goods companies. This finding contradicts Peter \& Simeon (2011), who discovered a positive significant relationship between corporate tax policy and the success of publicly traded consumer goods companies.

The coefficient value of -0.017 and the p-value of 0.010 indicate that as the company's age increases, so does its efficiency. This is due to the fact that the older a company is, the older its inventions are. This is because they do not incorporate new innovations into the business, which is why any new firm that introduces new innovations would expand profitably as a result of the implementation of new innovations. The findings of this study contradict those of Bassey and Arzizeh (2012), who discovered a positive relationship between HRA (age) and the output of Nigerian listed consumer goods firms.

The results show that total asset (TA) has a positive significant relationship with the output of the listed consumer goods companies in Nigeria, with a coefficient value of 2.9 and a p-value of 0.053 . This means that a company with enough total asset (TA) would be able to produce more profit if the total asset is used properly. This finding is consistent with Provirkina (2014), Soulunmi (2015), and Perera and Thirkaulala (2012), who found a statistically significant relationship between total asset and manufacturing firm efficiency. This result contradicts Yusuf (2013) results, which concluded that total asset has no major impact on manufacturing firm output. The findings show that manufacturing firms' Human Resource Accounting on Performance has a positive relationship with firm growth. This finding backs up previous research on the connection between Human Resources Accounting and the 
production of Nigerian manufacturing firms (Fariborz \& Raiasseka, 2011: Okpala \& Chidi, 2010; \& Stevens, 2004; Givord and Maurin, 2004; Zhu, 2004). This result lends credence to the argument that Human Resources Accounting will help a company gain a competitive advantage. This research supports the findings of Sowunmi (2015) and Perera and Thrikawala (2012), who discovered a statistically significant relationship between human resources and selected performance metrics such as return on asset.

\section{CONCLUSIONS}

This result lends credence to the argument that Human Resources Accounting will help a company gain a competitive advantage. This research supports the findings of Sowunmi (2015) and Perera and Thrikawala (2012), who discovered a statistically significant relationship between human resources and selected performance metrics such as return on asset. However, the study concludes that there is a positive significant association between the number of employees working over time and the success of Nigeria's publicly traded consumer goods firms. Because of the effect generated on employment due to division of labor, listed consumer goods companies with a large number of employees tend to make more profit. Furthermore, the research uncovers a negative correlation between leverage and the performance of Nigeria's publicly traded consumer goods firms. Consumer goods companies must reduce their liability (liabilities) while maintaining equity for shareholders in order to maximize their liquidity. Furthermore, there is a negligible connection between government taxation (measured in terms of VAT) and the performance of Nigeria's publicly traded consumer goods companies. This means that Nigeria's macroeconomic (fiscal) policies have no effect on the production of listed consumer goods companies. Furthermore, there is a negative correlation between age and the success of publicly traded consumer goods companies in Nigeria. This means that the older an organization becomes, the worse its output becomes. This is because businesses that have been granted holder status are more confident in launching new projects that will increase their sales. As a result, there is a positive significant relationship between total asset and manufacturing firm output in Nigeria. Since a firm's asset is intended to generate a higher return (profit) in order to keep the firm expanding, or more profitable, return on asset is one of the major determinants of how the firm performs. According to the results of this report, management of publicly traded consumer goods companies should weigh the number of employees when hiring because the larger the workforce, the higher the efficiency and profit potential of the company. Furthermore, management of publicly traded consumer goods companies should focus on providing sufficient total assets, as this leads to the generation of more economic gain to the company, resulting in increased profits. Furthermore, the study advises that publicly traded consumer goods companies avoid heavily relying on leverage as a source of funding because this has a negative impact on their financial results.

\section{REFERENCES}

Abiodun, E. J. (1999). Human resources management: an overview. Shomolu, Lagos: Concept 


\section{Publication.}

Abubakar, Salisu (2011). Human resource accounting and the quality of financial reporting of Quoted service companies in Nigeria. Unpublished Ph.D. Dissertation submitted to PG School of Ahmadu Bello University, Zaria.

Adamu, P.A. (2003). The impact of human capital formation on economic development in Nigeria: an error correction approach in human resource development in Africa. Selected papers for the year 2002 annual conference. The Nigerian Economic Society (NES), Part Two, 53-77.

Adebawojo, O. A.; Enyi, P. E.; \& Adebawo, O. O. (2015). Human asset accounting and corporate performance. American International Journal of Contemporary Research, 5(1), 45-52.

Adelakun, O.J. (2011). Human capital development and economic growth in Nigeria. European Journal of Business and Management, 3(9), 29-38.

Ahangar, R.G. (2011). The relationship between intellectual capital and financial performance: An empirical investigation in an Iranian Company. African Journal of Business Management, 5(1), 88-95.

Akintoye, I.R. \& Adidu, F.A. (2008). Optimising national growth through human resources investments. The European Journal of Scientific Research, 22(3), 433-443.

Al Mamun, S.A. (2009). Human resources accounting (HRA) disclosure of Bangladeshi companies and its association with corporate characteristics. $\quad$ BRAC University Journal, 6(1), 35-43.

Aliyu, M. G., Suhal, K., \& Suriyani, M. (2014). Investing in human resource development:empirical evidence from banking institutions of Malaysia and Nigeria. Journal of Economics and Sustainable Development, 5(12).

Arshad, R., Noor, A. H. M., \& Yahya, A. (2015). Human capital and islamic-based social impact model: small enterprise perspective. Procedia Economics and Finance, 31, 510-519.

Bassey, B. E.; \& Tapang, A. T. (2012). Capitalized human resources cost and its influence on corporate productivity: A study of selected companies in Nigeria. International Journal of Financial Research, 3(2), April 48-59.

Cascio, W. R. (1996). The role of utility analysis in the strategic management $\quad$ of organizations. 
Journal of Human Resource Costing and Accounting, $\quad$ 1(2), 85-95.

Charturvedi, A. (2013). Human resource accounting and its effect on organizational growth: A case study of Steel Authority of India Limited. International Indexed and Refereed Research Journal. 4, 43-44.

Danjuma, K. J., \& Ajike, A. M. (2016). Human capital efficiency and corporate performance: the Nigerian perspective. The International Journal of Business \& Management, 4(3).

Edward, J. G. \& Gary, L. (2001). Human resource accounting: A Critical Assessment. Human Resource Accounting, 3, 54-62.

Ekwe, M. (2014). Intellectual capitals and financial performance indices of deposit money banks in Nigeria: A comparative assessment. European Journal of Accounting Auditing and Finance Research, 2(2), $50-62$.

Ekwe, M.C. (2013a). The relationship between intellectual capitals and growth in revenue of deposit money banks in Nigeria. Research Journal of Finance and Accounting, 4(12), 55-64.

Ekwe, M. C. (2013b). The Relationship between Human Capital Efficiency and Financial Performance: An Empirical Investigation of Quoted Nigerian Banks. Research Journal of Finance and Accounting, 4(4), 148-154.

Flamholtz, E. G. (1971). A Model for Human Resource Valuation: A stochastic Process with Service Rewards. The Accounting Review, April, 253-267.

Flamholtz, E. G. (1972). Toward a Theory of Human Resource Value in Formal Organizations. The Accounting Review, October, 666-678.

Flamholtz, E. G. (1999). Current issues, recent advancements, and future directions in human resource accounting. Journal of Human Resource Costing \& Accounting, 4(1), 11-20.

Ghasempour, A. \& Yusof, M. A. (2014). Quality of Intellectual Capital and Human Resource Disclosure on the Firm Valuation. Open Journal of Accounting, 3, 59-70.

Grossman, R. J. (2000). Measuring up: Appropriate metrics help human resource prove its worth. Human Resource Magazine, 45(1), 28-35.

Happiness, O. O. \& Michael, C.E. (2014). Impact of training a d development on organizational 
effectiveness: evidence from selected public sector organizations in Nigeria. European Journal of Business and Management, 6(29).

Harbison, F. H. (1962). Human resources development planning in modernizing economies. International Labor Review, 453-458.

Ifurueze, M.S., Odessa, J. O \& Ifurueze, P. C. (2014). Impact of Aggregated Cost of Human Resources on Profitability: An Empirical Study. Journal of Business and Management, 3(2), 30-40.

Ismaila Yusuf (2013). The relationship between human capital efficiency and financial performance: an empirical investigation of quoted Nigerian banks. RJFA 4(4).

Izedonme, P. F., Odeyile, L. G. \& Kuegbe, K. (2013). Human resource accounting and its impact on Organizational performance. Journal of economics and sustainable development. 4(15).

Kajola, S.O., \& Adedeji, S.B. (2011). Human resources accounting: Old myth and new realities. Babcock Journal of Economics, Banking and Finance, 1, 110-121.

Kamal, M.H.H, Mat, R.C, Rahim, N.A., Husin, N, \& Ismail, I. (2012). Intellectual capital and firm performance of commercial banks in Malaysia. Asian

Economic and Financial Review 2(4):577-590

Khadija, I \& Abike, B. (2009). The usefulness of human resource accounting to organizations. The Nigerian Accountant, Lagos: Institute of Chartered Accountants of Nigeria, April/June, 4851 .

Kharal, M., Zai-ur-Rehman, M., Abrar, M \& Khan, M.S. (2014). Intellectual capital and firm performance: an empirical study on the Oil and Gas Sector of Pakistan. International Journal of Accounting and Financial Reporting, 4(1).

Micah, L.C., Ofurum, C.O., \& Ihendinihu, J.U. (2012). Firm's financial performance and human resources accounting disclosure in Nigeria. International Journal of Business and Management, 7(14) 67-75.

Odhong, A. E., Were, A. \& Omolo, J. (2014). Effect of human capital management drivers on organizational performance in Kenya. A case of Investment and Mortgages Bank Ltd. European Journal of Business Management, 2 (1), 341-356.

Oke, O. (2010). Transforming human capital potentials into organization capability. Journal of 


\section{Professional Administration, 37- 41.}

Olalere, T.O. \& Adenugba, A.A. (2013). Human capital development in first bank of Nigeria Plc. Mediterranean Journal of Social Sciences, 4(2), 783-801.

Olaniyan, D. A., \& Lucas, B. O. (2008). Staff training and development: A vital tool for organisational effectiveness: The European Journal of Scientific, 24(3), 326-331.

Onuka, A.O. \& Ajayi, K. (2012). Effects of manpower development on workers' job performance. European Journal of Educational Studies 4(3).

Onyinlola, O.M and Adeyemi, A.Z. (2014). An empirical analysis of human capital development and organizational performance in banking sector: a Nigerian experience. IJECM 11(7).

Oyinlola, O. M., \& Adeyemi, A. Z. (2014). An empirical analysis of human capital development and organizational performance in banking sector: a Nigerian experience. International Journal of Economics, Commerce and Management United Kingdom, 2(7).

Parham, S. \& Heling, G.W.J. (2015). The relationship between human capital efficiency and financial performance of Dutch production companies. Research Journal of Finance and Accounting, 6(8).

Prosvirkina, E. (2014). Human resources effectiveness in the Russian banking industry. Humanity \& Social Sciences Journal, 54 (3), 11-17.

Pulic, A. (1998). Measuring the Performance of Intellectual potential in knowledge Economy. $A$ paper presented at $2^{\text {nd }}$ World Congress on Measuring and Managing Intellectual Capital, McMaster University, Hamilton.

Rajashekharaiah, J. (2014). Emphasis on human resource management in quality improvement. A case study of quality awards 'criteria. International Journal of Economics, Commerce and Management, 2(1), 1-11.

Rehman, W.U., Rehman, C.A., Rehuman, H.U., \& Zaliad, A. (2011). Intellectual capital performance and its, implication on Corporate Performance: An empirical evidence from Moradabad sector of Pakistan. Australian Journal of Business and Management Research, 1 (5), 8-16. 
Saeed, F., Shekoofeh, F., \& Mahnaz, K. (2013). Impact of intellectual capital on financial performance. International Journal of Academic Research in Economics and Management Sciences, 2(1), 6 -17.

Sharma, A. (2012). Impact of human resource accounting on organizational performance. IOSR Journal of Business and Management (IOSR-JBM), 5(1), 25-31.

Okpala, P.O. \& Chidi, O.C. (2010). Human capital accounting and its relevance to stock investment decisions in Nigeria. European Journal of Economics, Finance and Administrative Sciences, 22 65-76.

Sowunmi, S. O., Eleyowo, I. O., Salako, M. A., \& Oketokun, F. O. (2015). Human resource development as a correlate of performance of the banking industry in Ogun state, Nigeria. Journal of Economics and International Finance, 7(5), $\quad$ 112-126.

Sumedrea, S. (2013). Intellectual capital and firm performance: A dynamic relationship in crisis time. Procedia Economics and Finance, 6, 137 - 144.

Waiganjo, E.W., Mukulu, E., \& Kahiri, J. (2012). Relationship between strategic human resource management and firm performance of Kenya's corporate organizations. International Journal of Humanities and Social Science, 2(10), 62-70.

Yusuf, I. (2013). The relationship between human capital efficiency and financial performance: an empirical investigation of quoted Nigerian banks. Research Journal of Finance and Accounting, 4(4).

Zehri, C., Abdelbaki, A. \& Bouabdellah, N. (2012). How intellectual capital affects a Firm's Performance. Austrian Journal of Business and Management Research, 2(8),

Zhu, Y. (2004). Responding to the challenges of globalization: human resource development in Japan. Journal of World Business, 39, 337-348 